\title{
Fungus ball of the paranasal sinuses: Report of two cases and literature review
}

\section{Bola fúngica dos seios paranasais: Relato de dois casos e revisão de literatura}

\author{
Guilherme Rasia Bosi', Gustavo Lisbôa de Braga', Tobias Skrebsky de Almeida', Adriana de Carli². \\ 1) Academic of Medicine of the University of Caxias do Sul. \\ 2) Master in Biotechnology for the University of Caxias do Sul. Otorhinolaryngologist doctor. Titular teacher of the Unit of Medical Education Otorhinolaryngologist- \\ Ophthalmic of the University of Caxias do Sul. \\ Institution: University of Caxias do Sul \\ Caxias do Sul/RS - Brazil. \\ Mailing address: Adriana de Carli - Colonel Flowers Street, 510, room 45 - Quarter: São Pelegrino - Caxias do Sul/RS - Brazil - Zip-code: $95034-060$. \\ Article received in April 19, 2010. Article approved in July 18, 2010.
}

\section{SUMMARY}

Introduction: Fungal ball of the sinuses is a not invasive infection that if characterizes for its chronicity, being the majority related with previous endodontic treatment. Affect mainly the breasts to maxillary; even so all the breasts can be involved. The main etiological agent is the Aspergillus spp. The computed tomography, had to characteristic the radiological presentations, suggests the diagnosis that is carried through definitively through histopathological analyses. The treatment standard-gold is the sinus surgery with average meatal antrostomy.

Objective: Reporting two cases of fungal ball of the sinuses and to stand out important aspects of this pathology.

Story of the Cases: Case 1) Patient of the feminine sex, 78 years old, presented itself with complaints of face pain has 6 months and previous history of endodontic treatment. To the physical examination it was evidenced purulent secretion presence in left average meatus. Ray X presented complete veiling of the breasts to maxillary left, while the computed tomography showed injury calcified in this place. Sinusotomy was become fulfilled that evolved well. Case 2) Patient of the feminine sex, 70 years old, looked attendance for history of sinusitis of repetition. To the physical examination no particularity was not perceived. The computed tomography, as well as the magnetic resonance, detected thickening of the mucous wall of the breasts to maxillary left, beyond a calcified mass. It was become fulfilled same sequence of treatment and the patient also evolved well.

Final Considerations: The fungal infection must be considered in the patients who if present with chronic sinusitis, that they do not answer to the antibiotic use and that they possess history of endodontic manipulation.

Keyword: mycetoma, sinusitis, maxillary sinusitis, sinuses, aspergillus. droaereo and presence of hypo intense of left maxillary sinus.

\section{RESUMO}

Introdução: Bola fúngica dos seios paranasais é uma infecção não invasiva que se caracteriza por sua cronicidade, sendo a maioria relacionada com tratamento endodôntico prévio. Acomete principalmente o seio maxilar, embora todos os seios possam ser envolvidos. O principal agente etiológico é o Aspergillus spp. A tomografia computadorizada, devido às apresentações radiológicas características, sugere o diagnóstico que é realizado definitivamente através de análises histopatológicas. O tratamento padrão-ouro é a cirurgia sinusal endoscópica com antrostomia meatal média.

Objetivo: Relatar dois casos de bola fúngica dos seios paranasais e ressaltar aspectos importantes desta patologia. Relato dos Casos: Caso 1) Paciente do sexo feminino, 78 anos, apresentou-se com queixas de dor facial há 6 meses e história prévia de tratamento endodôntico. Ao exame físico constatou-se a presença de secreção purulenta em meato médio esquerdo. O Raio X apresentou velamento completo do seio maxilar esquerdo, enquanto a tomografia computadorizada mostrou lesão calcificada neste local. Realizou-se sinusotomia que evoluiu bem. Caso 2) Paciente do sexo feminino, 70 anos, procurou atendimento por história de sinusites de repetição. Ao exame físico não se percebeu nenhuma particularidade. A tomografia computadorizada, assim como a ressonância magnética, detectou espessamento da parede mucosa do seio maxilar esquerdo, além de uma massa calcificada. Realizouse a mesma sequência de tratamento e a paciente também evoluiu bem.

Considerações finais: A infecção fúngica deve ser considerada nos pacientes que se apresentam com sinusite crônica, que não respondem ao uso de antibióticos e que possuem história de manipulação endodôntica.

Palavras-chave: micetoma, sinusite, sinusite maxilar, seios paranasais, aspergillus. 


\section{INTRODUCTION}

Rinosinusites (RS) is a pathology that reflects a contiguously inflammatory or infectious process of the nasal region and to the sinus. It is a clutter that annually affects more than 31 million Americans of all the ages and sorts (1). The RS can be divided in acute (when it lasts up to 12 weeks) or chronicle (lasting 12 weeks more than), a time that does not have histopathological substratum that it differentiates the acute form of the sub-acute. It also can be classified in viral, bacterial, fungal RS or alérgica (2).

The frequency of fungal rinosinusites (RSF), although to be uncommon, it has increased in last the two decades (3). In patients with chronic RS, $6 \%$ to $12 \%$ will go to present fungus in the culture or in histopathological study (4). Has little time also was observed that its classification is of utmost importance to predict of accurate form the prognostic and to optimize of form accomplishes its therapy. It has two basic types of RSF: the invasive form and the not-invasive one. Moreover, it still has 5 distinct subtypes depending on the immunological system of patient (5): in immunosuppressed sudden the acute/ invasive form and invasive indolent/chronic (that it can also be disclosed in immunocompetent, in the granulomatosis or not-granulomatosis form); in immunocompetent, the saprophytic settling and the fungal ball; e in atopics, the allergic fungal sinusitis.

The present series of cases will approach two cases of not invasive RSF in a private clinic of Caxias do Sul, with its diagnostic evolutions and its treatments, beyond one brief revision of literature on the pathology.

\section{Case Report}

Case 1) Patient of the feminine sex, pensioner, 78 years, presented itself in a particular doctor's office complaint with cheek pain with irradiation for superior dental arches to the left has about six months. It carried through evaluation with dentist and, although to have endodontically treatment in the $\# 26$ in the past, was set free. It told that after exposition the climaticalterations had a compatible picture with infection of superior aerial ways and received a treatment with antibiotic that alleviated the symptoms temporarily. Its only factor of relief was the anti-inflammatory frequent use of not steroidal (AINE). The x-ray brought for the patient presented complete veiling of left maxillary sinus. To the physical examination and nasal endoscopy, a shunting line of septum was evidenced and the purulent secretion presence in left average meatus. Computed Tomography (TC) of face was requested that presented injury with calcification of the left maxillary sinus. A sinusotomy was indicated to maxillary endoscopy to the left with anattomicopathological and specific culture for fungus (Figure 1). The postoperative evolution elapsed without occurrences.

Case 2) Patient of the feminine sex, pensioner, 70 years, that if presented in a particular doctor's office directed which had to a description of sinusitis of repetition and allergic rhinitis. Was in use of nasal furoate of fluticasone spray and it did not present complaints. It brought a TC of face that presented thickening of the mucous covering of the left maxillary sinus with hydro-aereal level associate, identifying itself mass with density of soft parts next to the medial wall and to its den, with small calcifications of permeate (Figure 2). Excessively sinus paranasal showing usual aeration and development. To the physical examination and nasosinusal endoscopy no particularity was found. Magnetic Resonance (RM) of face was requested that if presented with hypointense, attacking the socket to left maxillary, which showed fast parietal thickening, with presence of hydro-aereal level and, also, structure with dense standard, showing calcification component associated (Figure 3). This hypointense to the RM with hyper attenuation of TC is typical signals of fungal ball. It was carried through the same sequence of surgical treatment and examinations of etiological diagnosis. This patient also evolved well.

Both the cases had presented Aspergillus spp as etiological agent.

\section{DISCUSSION}

Fugal ball is described as a not invasive accumulation of a dense conglomeration of fungal hyphae in a paranasal sinus. It is characterized by a mass of fungal hardened remaining portions and mucus, with gradual growth in the sinusal socket, without involvement of the underlying mucous membrane (3). Fungal balls had been classified erroneously as maduromycosis or aspergilloma in the past. During the last decades has had an apparent increase in the diagnosis of these pathologies (3). Fungal balls had been found in 3,7\% of the patients operated in the Mayo Clinic for chronic inflammatory conditions of the paranasal sinus (6). The incidence can be artificially increased of innumerable forms, including the best detention through radiological evaluations and greater expectation of life (7).

The average age of attacking is 64 years, having the feminine sex $64 \%$ predominance, befitting with the characteristics of the told cases. The individuals are typically immunocompetent. The place more frequent 


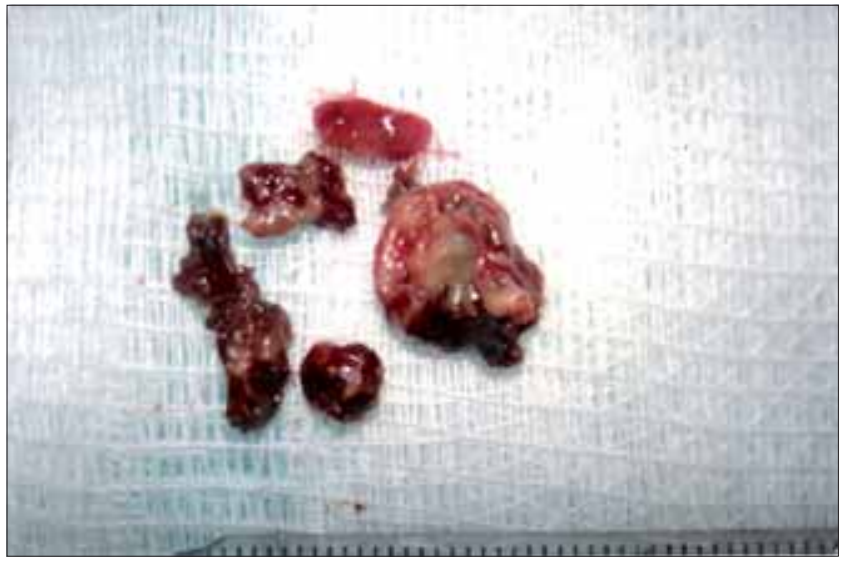

Figure 1. Surgical part after maxillary sinusotomy.

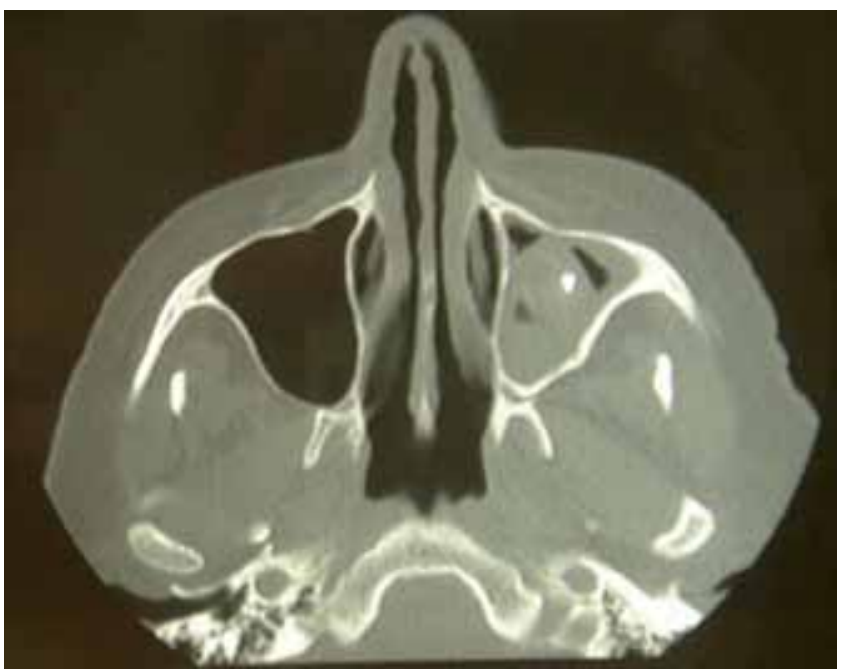

Figure 2. TC of face presenting thickening of the mucous covering of the maxillary sinus left and mass of density of soft parts with calcifications.

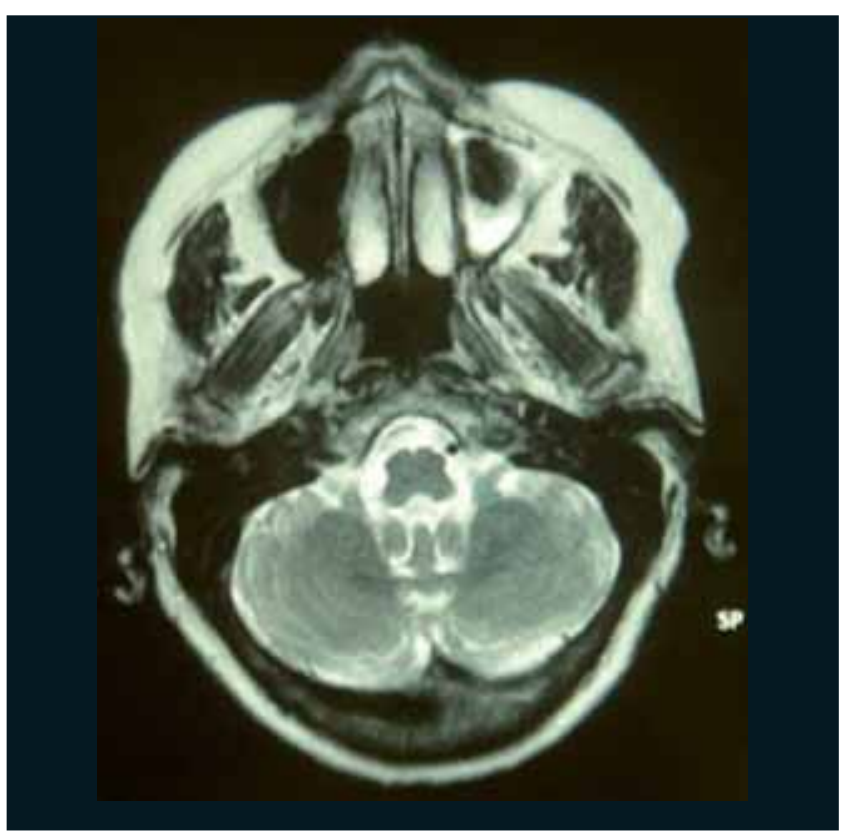

Figure 3. RM of face with hydro-aereal level and presence of hypointense of maxillary sinus left. involved is the maxillary sinus, followed for the sphenoid sinus (8). The case 1 presented a description of previous dental treatment, being this present characteristic in about $84 \%$ of the diagnosised patients with fungal ball (6). In a case-control study, the risk to develop the illness in submitted patients the endodontic treatment was 14 times bigger that of the patients without treatment (9).

The pathophysiology of the fungal ball is not totally understood, existing some theories to try to explain its appearance. The aerogenic theory claims that the inhaled spores of fungus if would deposit in the paranasal sinuses, becoming pathogenic when the conditions in the interior of the sinuses if became relatively anaerobic. Another theory suggests that the functional blockage of the sinusal ostium could act as an inductive factor, and that the fungal growth could be favored by the hypoxic and anaerobic conditions. Moreover, the reduction of the ventilation would diminish $\mathrm{pH}$, favoring the growth of hifas (10). One another considered mechanism conjectured that the growth of hyphae can be extended for a long period of time, with proliferation episodes alternating with longer periods of inactivity. Super infections could take the episodes of acute sinusitis, and the resultant purulent secretion would consist of an ideal nutritional way to boosting the fungal growth. Finally, the hypothesis of the ticket of dental sealant exists contends zinc oxide to the maxillary sinus could be an important inductive factor of necrotic alterations and inflammatory in the mucous, what would favor the fungal growth (11). This last hypothesis, however, it does not explain the appearance of fungal balls in other paranasal sinus.

The fungal ball can be asymptomatic, as it occurred in the first case, or can simulate chronic rhinosinusitis pictures (7). Frequent symptoms include nasal blockage, purulent nasal secretion, sensation of unpleasant smell and face pain. Less common symptoms include convulsions, epistaxis, proptosis, fever, cough and blurred vision. The symptoms generally last a long period of time and can be gifts for months or until years (8).

The diagnosis of fungal ball must be considered in the cases of recurrent sinusitis or refractory to the treatments with antibiotics previously used (case 2) and especially when they will be unilateral $(6,8)$. Radiological evidences, through x-rays and, mainly, TC suggest this strong diagnostic (11). However, the definitive diagnosis is based on the macroscopic characteristics and histopathological of the surgery part $(6,8)$. Frequently, the cultures present resulted negative, being that in only $23-50 \%$ of the cases the cultures helping (8). Of these, the Aspergillus fumigatus species grows more than in $90 \%$ of the cases (12). In the 
told cases, the responsible etiological agent were the Aspergillus spp. After to consider some criteria diagnostic and to compare them with the finding in 20 cases published in medical literature, DESHAzO et al arrived the five criteria for the diagnosis of maduromycosis of the paranasal sinus (13).

The examination of image of choice for the diagnosis of maduromycosis is the TC. The finding most common in this examination is the complete or partial opacification of the attacked sinus. Microcalcifications or spots with metallic density also is found in about a third of the cases of opacification of one sinus (6).

The best form of treatment of maduromycosis of paranasal sinus is the surgery, since the anti-fungal, topic or systemic drugs, are not indicated (14), except in the immunodepression cases, where some authors recommend adjuvant treatment with the use of antifungal systemic, as itraconazole (8).

Two forms of surgical procedures for removal of the fungal ball in the maxillary sinus are described in medical literature: the historical procedure of Caldwell-Luc, who consists of the opening of canine pit for attainment of access to the maxillary sinus; beyond the surgery for it saw endoscopy, standard-gold actually (14). The two cases told in this work had been dealt with sinusotomy for endoscopy via.

The boarding of the paranasal sinus saw endoscopy aims at to the natural opening of the ostium of the attacked sinus, in intention to recoup its draining and ventilation. In case that it has mucous polypoid next to the average meatus a debridement can be carried through. Moreover, a wide antrostomy can be created removing great part of posterior fontanelle and connecting a possible secondary ostium to the area of the ostium to natural maxillary. Washings with aspirator must be carried through the procedure (14).

This procedure cause little damages to the patient, as well as reestablishes the ventilation and the draining of the sinus to its natural ostium (14). On the other hand, this surgery presents a problem technician: it is not possible to visualize the angle formed for the bone of lachrymal ducts and the previous wall of the maxillary sinus. In this point, it can remain a fungal particle concentrate after the surgery, what it can generate relapses (15).

When the fungal ball attacks the sphenoid sinus or the ethmoidal, the choice boarding is, respectively, endonasal sphenoid or complete ethmoidectomy. Already in the rare cases where the engaged sinus is the frontal a endonasal access generally is possible (14).
Table I. Criterion of physician-pathological considered for the diagnosis of maduromycosis of the paranasal sinus.

I) Evidence of opacification of the sinus with or without flocculentcalcifications.

2) Mucopurulent content, malodorous or with similar coloration to the clay inside of a paranasal sinus.

3) Adense of hyphae becomes entangled, butadjacent conglomeration to the respiratory mucosa of the sinus.

4) Chronic inflammatory reply of changeable intensity in the adjacent mucosa to the fufungal elements. This reply it includes lymphocytes, cells of the plasma, mast cells and eosinophils, without predominance of eosinophils or granulomatosis reply. Allergic Mucilage is absent in the haematoxylin-eosine coloration.

5) Without histology evidence of fungal invasion of the mucous, associate the sanguineous vases or to the adjacent bone, visualized with colorations microscopically special for fungus.

Adapted of deShazo etal, 1997( |3).

\section{FINAL COMMENTS}

Although the advance of the diagnostic methods and the examinations of image, the diagnosis of fungal sinusitis still remains a challenge. The fungal infection must be considered in all the patients with chronic sinusitis, when it does not have adjusted therapeutically reply or in recurrent unilateral sinusitis, being more gifts in those submitted previous the endodontic treatments. Considered an exclusion diagnosis, many times the attacked patients arrive at the doctor's office already had passed a health professional for more than, as the told cases. In these cases, a TC of paranasal sinus must be considered, but its definitive diagnosis is based on macroscopic and histopathological analyses of the surgical part.

\section{BibliograPHICAL REFERENCES}

1. Infectious rhinosinusitis in adults: classification, etiology and management. International Rhinosinusitis Advisory Board. Ear Nose Throat J. 1997, 76(12 Suppl):1-22.

2. Associação Brasileira de Otorrinolaringologia e Cirurgia Cérvico-Facial. Diretrizes Brasileiras de Rinossinusites (suplemento). Br J Otorhinolaryngol. 2008, 74(2).

3. Nicolai P, Lombardi D, Tomenzoli D, Villaret AB, Piccioni $\mathrm{M}$, Mensi M, et al. Fungus ball of the paranasal sinuses: experience in 160 patients treated with endoscopic surgery. Laryngoscope. 2009, 119(11):2275-9. 
4. Taxy JB. Paranasal fungal sinusitis: contributions of histopathology to diagnosis: a report of 60 cases and literature review. Am J Surg Pathol. 2006, 30(6):713-20.

5. Ferguson BJ. Definitions of fungal rhinosinusitis. Otolaryngol Clin North Am. 2000, 33(2):227-35.

6. Grosjean P, Weber R. Fungus balls of the paranasal sinuses: a review. Eur Arch Otorhinolaryngol. 2007, 264(5):461-70.

7. Robey AB, OBrien EK, Richardson BE, Baker JJ, Poage DP, Leopold DA. The changing face of paranasal sinus fungus balls. Ann Otol Rhinol Laryngol. 2009, 118(7):500-5.

8. Ferguson BJ. Fungus balls of the paranasal sinuses. Otolaryngol Clin North Am. 2000, 33(2):389-98.

9. Mensi M, Piccioni M, Marsili F, Nicolai P, Sapelli PL, Latronico $\mathrm{N}$. Risk of maxillary fungus ball in patients with endodontic treatment on maxillary teeth: a case-control study. Oral Surg Oral Med Oral Pathol Oral Radiol Endod. 2007, 103(3):433-6.

10. Stevens MH. Primary fungal infections of the paranasal sinuses. Am J Otolaryngol. 1981, 2(4):348-57.
11. Stammberger H, Jakse R, Beaufort F. Aspergillosis of the paranasal sinuses $\mathrm{x}$-ray diagnosis, histopathology, and clinical aspects. Ann Otol Rhinol Laryngol. 1984, $93(3 \mathrm{Pt}$ 1):251-6.

12. Klossek JM, Serrano E, Peloquin L, Percodani J, Fontanel JP, Pessey JJ. Functional endoscopic sinus surgery and 109 mycetomas of paranasal sinuses. Laryngoscope. 1997, 107(1):112-7.

13. deShazo RD, OBrien M, Chapin K, Soto-Aguilar M, Swain $\mathrm{R}$, Lyons $\mathrm{M}$, etal. Criteria for the diagnosis of sinus mycetoma. J Allergy Clin Immunol. 1997, 99(4):475-85.

14. Costa F, Polini F, Zerman N, Robiony M, Toro C, Politi M. Surgical treatment of Aspergillus mycetomas of the maxillary sinus: review of the literature. Oral Surg Oral Med Oral Pathol Oral Radiol Endod. 2007, 103(6):e23-9.

15. Chobillon MA, Jankowski R. What are the advantages of the endoscopic canine fossa approach in treating maxillary sinus aspergillomas? Rhinology. 2004, 42(4):230-5. 